\title{
Comparison of Different Gouge Collections from Central Sudan
}

\section{Katarína Kapustka $^{a}$ and Małgorzata Winiarska-Kabacińska ${ }^{b}$}

\begin{abstract}
This article represents a basic comparison of gouge collections from three different sites (Esh Shaheinab, Fox Hill and Kadero). These sites have revealed important collections of lithics from the Early Neolithic period in Central Sudan. Gouges were chosen as an important marker of various activities, and these were studied on the basis of examining this type of artefact. This paper presents basic observations on the technology and function of these artefacts.
\end{abstract}

KEY-WORDS: Nile valley, Central Sudan, Neolithic, lithic technology, use wear

\section{INTRODUCTION}

Gouges are one of the iconic artefacts of African prehistory and are present on most Neolithic sites in Central Sudan. There are many smaller collections, consisting of a few or few dozen pieces, yet there are some remarkable collections that include hundreds of pieces and we propose comparing the basic characteristics of the items in these collections.

Despite advances in their study, the first definitions of this artefact type are still valid today:

"Artefact conical in outline. The dorsal face is either polished or polished and flaked. The ventral face is flaked only. The cross-section is a thin pointed oval. The working hollow edge is obtained by oblique flaking from the polished side" (Caton-Thompson and Gardner 1934: 20).

There have been several typologies established (Tixier 1962; Magid 1989) but they do not fit our material very well. As we understand gouges, they are usually of one main type, with some exceptions and any differences in their appearance are usually caused by reworking and repairs.

a Institute of Archaeology of the Czech Academy of Sciences; Letenská 4, Praha I - Malá Strana, II8oI, Czech Republic; e-mail: culakova@arup.cas.cz; ORCID: 0000-0003-3174-5614

$b$ Poznan Archaeological Museum; Wodna Street 27, 6I-78I Poznan, Poland; e-mail: mwinkab@interia.pl; ORCID: 0000-0001-5927-8873 
I66 Katarina Kapustka and Matgorzata Winiarska-Kabacinska

The function of gouges has been discussed since the beginning of study of them and most scholars associate their use with woodworking (Arkel 1953; Tixier 1962), but no use wear analysis has been done on them yet. We have begun to prepare material for a detailed use wear analysis and technological study of this type of artefact, although this work is not yet finished. But here we would like to present some preliminary observations on this topic.

\section{DESCRIPTION OF THE COLLECTIONS}

The three most numerous collections of gouges from Central Sudan were chosen for this study (Fig. I). These sites contained both settlement and funerary features. The collection from Esh Shaheinab contains mostly finished gouge pieces, so we focused mainly on them in our comparative analysis, not regarding production waste, because it is not present in the museum collection in all its stages. Production waste is well known from the Kadero site and even better from the site of Fox Hill. The collections of gouges from all three sites are easily comparable, although there are some differences.

At all sites, the size of pieces present were recorded, as well as raw materials and polish on the pieces. To compare technological observations, pieces were sorted into categories representing different stages in the life of the artefact and therefore reflect the differences between various activities that were taking place at the site (categories are described in detail in Kapustka etal., 2019).

\section{Esh Shaheinab}

The collection from Esh Shaheinab comes from the excavation of A. J. Arkell, conducted during 1949-1950 (Arkell 1953). The finds are stored in the National Museum of Sudan in Khartoum, where 642 pieces were accessible in total. Detailed locations within the excavated area are not accessible at the moment, so these pieces were treated similarly to the surface finds from the Sabaloka region.

The gouges from Esh Shaheinab were studied during the autumn of 2017 and spring of 20I8. The collection mostly consists of red rhyolite, but there are examples of the use of grey rhyolite. For the pieces which were made from other raw materials than rhyolite it is not clear if they could be properly associated with gouges. Within this collection is the greatest span in sizes, it includes very small and very big pieces. It is difficult to compare the length of pieces because the objects were often reworked after use or breaking the piece, so the length often changed even for functional pieces. We see the width and thickness of pieces as better markers, as they usually do not change a lot, even when the object was repaired. It is here that size differences can be better observed in all studied collections. However, the majority of pieces in all studied collections (more than 95\%), belong to the same size group. 
The gouges considered to be in the small category were those with width under $30 \mathrm{~mm}$, they represent $3 \%$ of all pieces. Those regarded as big pieces had a width over $55 \mathrm{~mm}$ and they represent $\mathrm{I} \%$ of all pieces. The maximum width that was recorded was $67 \mathrm{~mm}$. The ratios between width and thickness were stable, although length changed according to the repairs of some pieces.

The raw materials from which these pieces were produced was rhyolite, $95 \%$ were made from red rhyolite and $5 \%$ from grey. The most probable source of this raw material is seen as the area of Sabaloka, on the Sixth Nile Cataract. The Esh Shaheinab pieces were $75 \%$ polished, the majority of them (9I\%) on one (convex) face. On the one hand we observe that at this site there are quite big pieces compared to other collections and on the other, there was really economic raw material use, where even broken gouges sometimes served as source of raw material for crescent production.

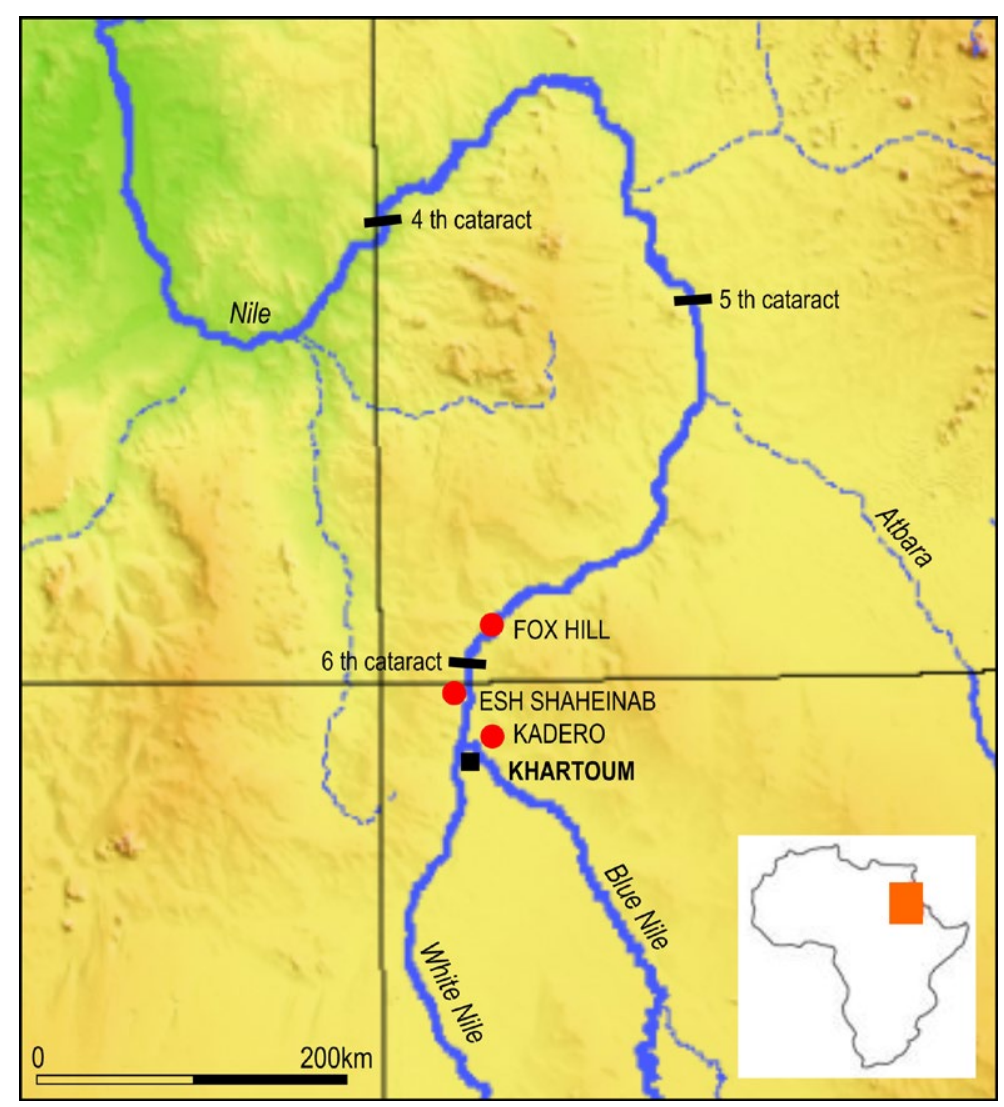

Fig. I. Map of sites mentioned in text. Drawn: J. Kędelska. 
I68 Katarina Kapustka and Matgorzata Winiarska-Kabacińska

\section{Fox Hill}

Sabaloka (West) is the area where the best-known sources and outcrops of red rhyolites that were used for local gouge production are found. The material analysed in our research are from expeditions by the Czech Egyptological Institute and conducted by Lenka Varadzinová during 20II-20I8 (Varadzinová et al., 20I8). There were 5 sites identified with the presence of gouges and these are so far all the known sites with gouges from the Western part of Jebel Sabaloka.

Fox Hill is the most significant site, with numerous records of prehistoric occupation. More sites within this region exist with a presence of gouges such as the Donkey Site, Grove Site, Lake Basin, Rhyolite Site and Tabya Hassaniya. All these sites also have remains of occupation during the Mesolithic and earlier and/or later periods. The studied collection consists mostly from surface finds. The total number of studied gouges and gouge-like artefacts is 360 items. Of these, 32I came from Fox Hill and the rest from the other 5 sites. Fox Hill has therefore been chosen for our comparative analysis because it has a similar number of gouge finds to Kadero.

The finds from the Fox Hill site were mostly collected during systematic surveys. Only three of the Fox Hill finds come from the excavated trenches. No gouges found were in burials or any other type of context, where primary position is assured. For these reasons, the gouges from excavations are treated in the same way as the pieces from surface surveys. The sizes of the specimens from Sabaloka were recorded in a very detailed way, although the results are similar to what we recorded in the Esh Shaheinab assemblage.

Small and large size artefacts are present only in very low numbers. The collection is dominated by medium size pieces with widths from 35 to $50 \mathrm{~mm}$. Large pieces of width more than $55 \mathrm{~mm}$ represent only I\% of all pieces and small pieces with width up to $30 \mathrm{~mm}$ represent $3 \%$ of the collection. The raw material from which these pieces were produced was rhyolite ( $88 \%$ red and $\mathrm{I} 2 \%$ grey) and the most probable source of this raw material is the area of Sabaloka, on the Sixth Nile Cataract.

Fox Hill is the only site where less than half (28\%) of all pieces were polished, compared to other sites. The majority of these ( $93 \%)$ were polished from the convex side only.

\section{Kadero}

The Kadero site is located several kilometres north of Khartoum and was excavated and studied by Lech Krzyżniak in 1972-2003 (Chłodnicki et al., 20II; see more references there). The settlement discovered on the site is dated to the Early Khartoum and Khartoum Neolithic, while the accompanying cemetery functioned mainly during the Khartoum Neolithic and partially also later, in Meroitic and Post-Meroitic times.

The gouges analyzed, 234 specimens in total, were mostly found in cultural layers of the settlement, sometimes from the site surface and only single pieces from burials. 
The collection, stored in the Poznan Archaeological Museum, was analysed by Michat Kobusiewicz (Kobusiewicz 20II).

Because gouges from the Sabaloka area were studied with the use of a different methodology regarding technological aspects, for comparative reasons the collection from Kadero was re-analyzed using this new methodology, different from M. Kobusiewicz's study.

Part of the Kadero collection was measured, although not in such a detailed way as the gouges from other sites. The collection is far more fragmented than the previous two, although most of the pieces fit well into the medium category where the width of piece varies between 35 to $50 \mathrm{~mm}$. The raw material from which the pieces were produced was rhyolite, $80 \%$ red and $20 \%$ grey. The most probable source of this raw material is the area of Sabaloka, the Sixth Nile Cataract. At Kadero, most of the pieces $(85 \%)$ were polished, the majority $(89 \%)$ on the convex face.

\section{PRELIMINARY OBSERVATIONS OF FUNCTION (USE WEAR ANALYSIS)}

The function of gouges has been studied by numerous archaeologists carrying out excavations of Sudanese Neolithic sites over the past few decades (Arkel 1953; Haaland 198I; Caneva 1988; Krzyżaniak 1992). However, interpretations of how and what they were used for have never been based on microwear studies. This method, combining observations of original artefacts and experimental pieces, allows the observation and documentation of manufacturing and utilization traces. Therefore an attempt was made to apply microwear analysis in order to establish the function of gouges. During the first stage of research, the type of traces that appeared in the course of its production were observed, whether complete pieces from archaeological collections were used or only stored for future activities. Observations were done with the help of stereoscopic and metallographic microscopes with magnifications ranging from 6.3 to 500 times.

For comparative studies, an experimental specimen was made by Petr Zítka using hard and soft mineral hammers on material (red rhyolite) from outcrops located by the Nile Sixth Cataract. That unpolished specimen has both its transversal edge and sides sharpened (Fig. 2). There were no traces observed caused by a hard hammer, while particles of mineral raw material were found on the specimen edges coming from the soft hammer as a result of percussion into the gouge edge (Fig. 2). A bone pressure tool also left organic remains on the edge during final edge retouching (Fig. 2).

The archaeological finds that were analysed originated from the Sabaloka and Kadero sites. Complete gouges from Sabaloka were not polished or smoothed and carry damage on the edges produced during their use (Fig. 3). The edges are blunt and side edges 
I70 $\mid$ Katarina Kapustka and Matgorzata Winiarska-Kabacińska

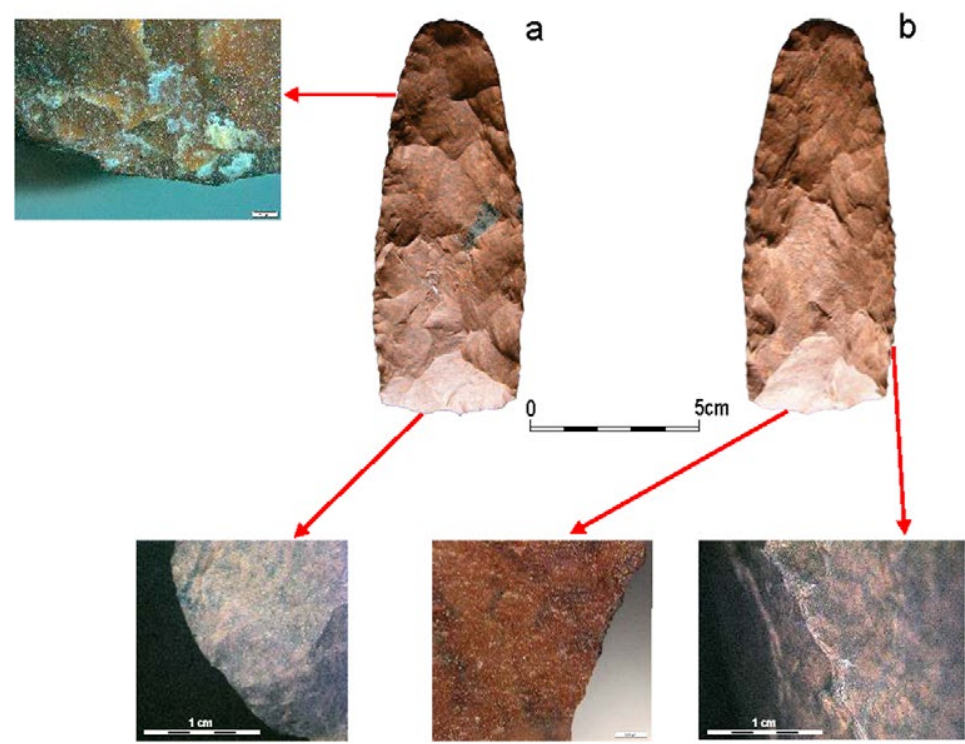

Fig. 2. Experimental gouge: a - flat face, organic remains, cutting edge; $\mathrm{b}$ - convex face, cutting edge, edge of side.

Photo and computer graphics: J. Kędelska and M. Winiarska-Kabacińska.
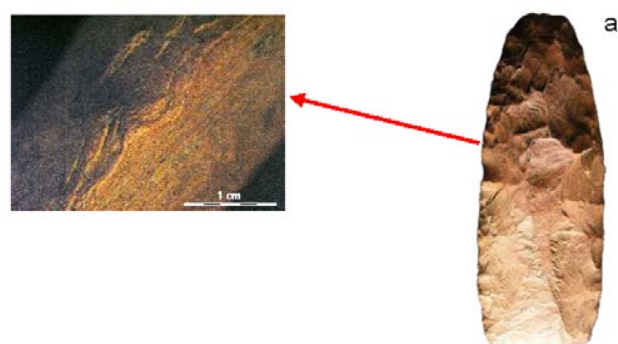

a
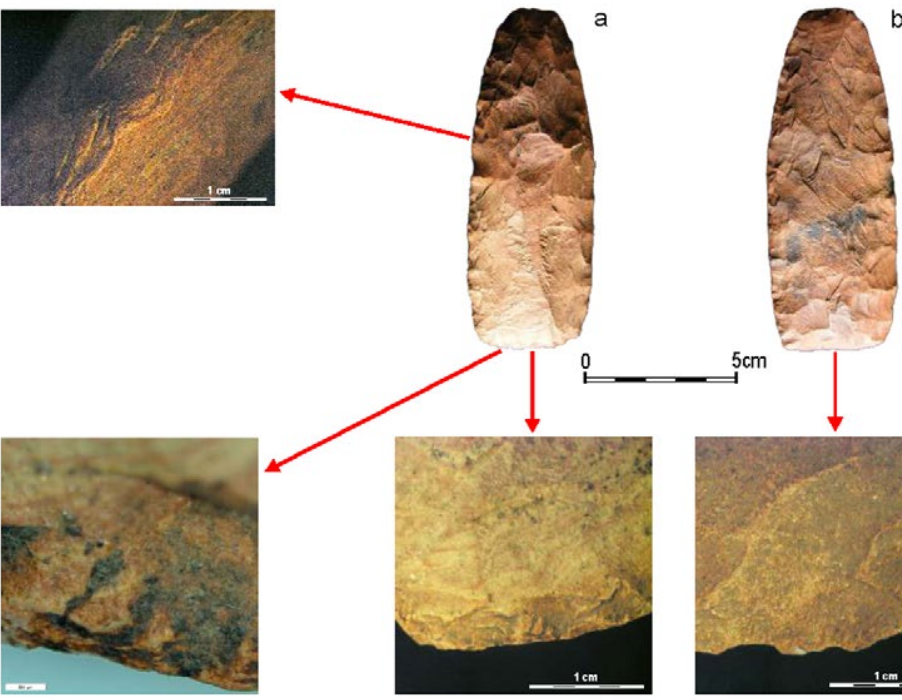

$5 \mathrm{~cm}$
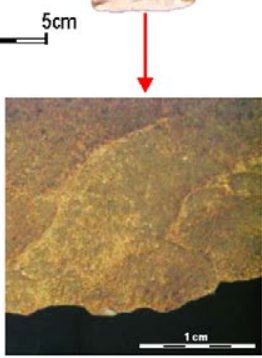

Fig. 3. Sabaloka, whole gouge: $\mathrm{a}$ - convex face, edge of side, cutting edge; $\mathrm{b}$ - flat face, cutting edge. Photo and computer graphics: J. Kędelska and M. Winiarska-Kabacińska. 


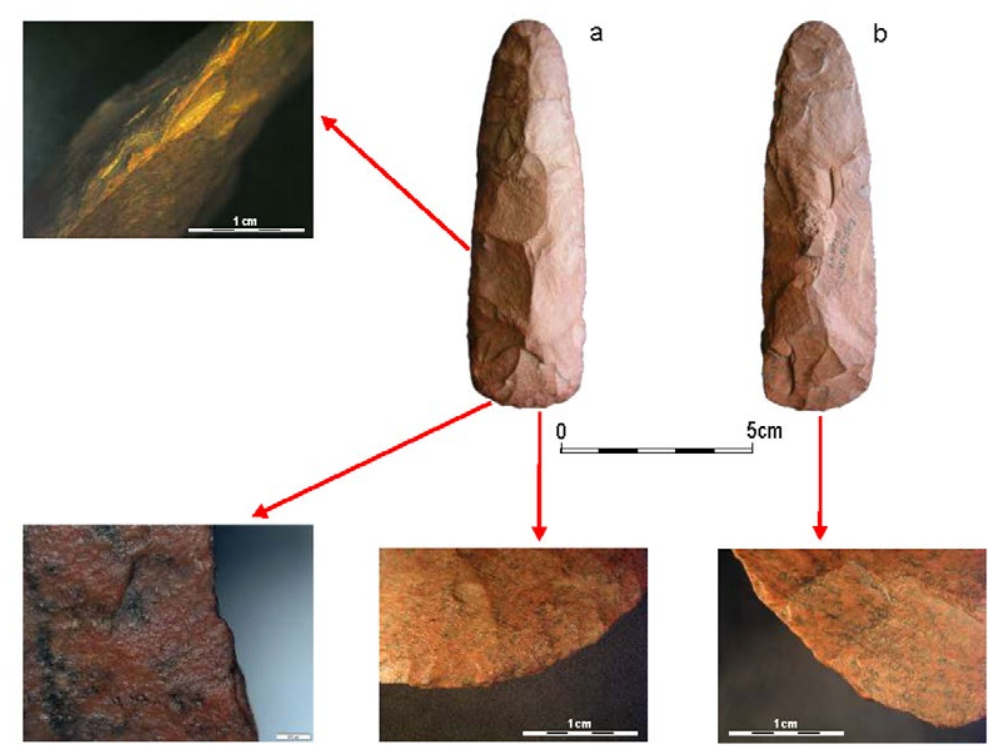

Fig. 4. Kadero, whole gouge; convex face: $\mathrm{a}$ - edge of side, cutting edge; $\mathrm{b}$ - flat face: cutting edge. Photo and computer graphics: J. Kędelska and M. Winiarska-Kabacińska.

and butts blunt and polished. There are no evident traces of hafting recorded. Similar traces are also found in the case of Kadero (Fig. 4).

After that initial research, one may say that complete, unpolished gouges carry traces of use but not traces of manufacturing, perhaps "erased" during exploitation. It is still an open question remains over what the gouges were used for. Certainly these were not tools used like mattocks to soften the ground on sorgo plantations (Haaland I98I). Perhaps they were used for wood-working (the very hard wood of the acacia tree), processing of plants or tree fruits (Doom palm - Hyphaena thebaica) as traces of use observed on working edges are very abrasive. On the other hand, bones and especially antlers and horns are usually much softer materials that don't cause such intensive damage.

Experimental works and microwear observations of archaeological finds from Sabaloka and Kadero will be continued, concentrating on studies of other types of gouges.

\section{TECHNOLOGICAL OBSERVATIONS}

Technological approaches are not very common within African lithic studies. However they reveal important observations that help us to more clearly understand the basic principles of production and the consumption processes. Within this rather 
I72 Katarina Kapustka and Matgorzata Winiarska-Kabacińska

limited representation of all three sites, we will mention the most important points of our study:

I. Gouges were produced in highly standardized ways and basic standards are similar for all studied sites. This can be seen thanks to level of symmetry, standardized shape of back and identical proportions at all sites.

2. Gouges were produced in a highly professional way, they were not produced by everybody, their production was done by specialists who were able to predict the results of their actions in their production. This can be seen thanks to the parallel negatives and pieces with mostly no serious production mistakes.

3. The preferred raw material was red rhyolite and colour was more important than quality, there are often visible heterogeneities in the raw material, but only in the red variety. When other types of raw material (including different colour variants of rhyolite) were used, it was usually of perfect quality and this happened only exceptionally.

4. Production was conducted not only in the surroundings of raw material sources but at more distant places (e.g., Shaheinab), as may be confirmed by object categories present on these sites and also production waste. But the further the site is from the source of the raw material, the more professional the production process is and less visible are traces of the learning process. It seems that the further the findspot was from the source, the more professional pieces had been exported.

5. There are differences within the economy of these pieces. At sites near the source, they are not repaired so much, but further from the source, specimens were abandoned only in a more exhausted way, so it seems their value had risen the further it was being used from the source.

6. Polish was done by hand without any special devices and is easily visible thanks to the fact that lines are not parallel. Another important point is that polish is connected to the re-working and repairing of the pieces, as it can be seen that reworked pieces are more often polished than other products. It can be seen that the ratio of polish also rises the further the findspot is from the raw material sources.

\section{COMPARATIVE ANALYSIS}

All collections have initially been presented in quite a detailed way: Esh Shaheinab (Arkell 1953), Fox Hill (Kapustka et al., 2019) and Kadero (Kobusiewicz 20II). So our main aim is not to describe these collections in detail here. We see our contribution to the topic of gouges as comparative analysis and microwear observations.

Comparison of collections of this size is not often done. Usually it is difficult to present large collections in a clear and comprehensive way and comparing them is often very difficult. For comparative analysis we used the analytical categories proposed in an earlier work (Kapustka et al., 2019). These categories document various phases 
in the life of the artefact, from its production to its discard. Material from all sites was sorted according to these categories and this was used as a basis for comparative analysis (Table I). Their comparative ratios show differences between collections themselves, especially within the production process and economy of raw material use.

First of all, the pieces were divided into polished and not polished gouges. Polish is connected to the repair and reworking of the artefact. Its percentage is much lower in surroundings close to the raw material source and higher in more distant sites as Esh Shaheinab and Kadero (see Fig. 5). Basically we see polished items as repaired/ reworked pieces. But there are also reworked/repaired pieces within the unpolished ones, especially at the site of Fox Hill.

Unpolished pieces typically offer a wider variety of categories (Fig. 5). Pieces also document the production and learning processes. The production processes of the material of Fox Hill are especially well shown and an important number of pre-forms which were not finished are also present. The situation is similar when we look at the Esh Shaheinab material, where unfinished pieces are present as well, but in a much lower percentage. It is interesting that the number of pieces apparently knapped by novices is quite high in the Esh Shaheinab assemblage. So it seems that the material that was transported to Esh Shaheinab and Kadero was different.

Whereas in Esh Shaheinab, there were signs that production was taking place on site, in Kadero we have no signs of primary production, so it seems that pieces were transported there in finished form. The number of pieces intentionally broken does not correlate with this production process. So it seems that this voluntary breaking could be a result of unsatisfied craftsmen, but for the material from Kadero it also had some different causes. Selection of raw material, regarding pieces chosen for export was quite careful, because there are no pieces broken due to natural causes outside the raw material sources area.

Within the category of polished pieces (see Fig. 6) in all collections most numerous are the reworked rear parts of original pieces. This category is connected to the polishing process, as it can make reworking considerably easier. In the Kadero collection, it is important to note how high, compared to other collections, the category of pieces broken during use is. At Kadero, it seems this was main reason pieces were abandoned. In Esh Shaheinab and Fox Hill, even pieces that were still useful were often abandoned. In the material from these two sites, it seems that the production process was ongoing, while in Kadero it seems that only consumption was at play.

Basically we can see that from a techno-economic point of view there are clear differences between the sites presented. In Fox Hill, variability is highest, the site is the nearest to the raw material sources. At the Esh Shaheinab site, there was also production taking place, but the variety of categories is considerably lower and it seems that use of raw material and control over its consumption was much higher. In Kadero it seems that pieces were received in a finished condition and were only repaired at the site. 
$\mathrm{I} 74$ Katarina Kapustka and Matgorzata Winiarska-Kabacinska

Ratio of polished and not polished pieces
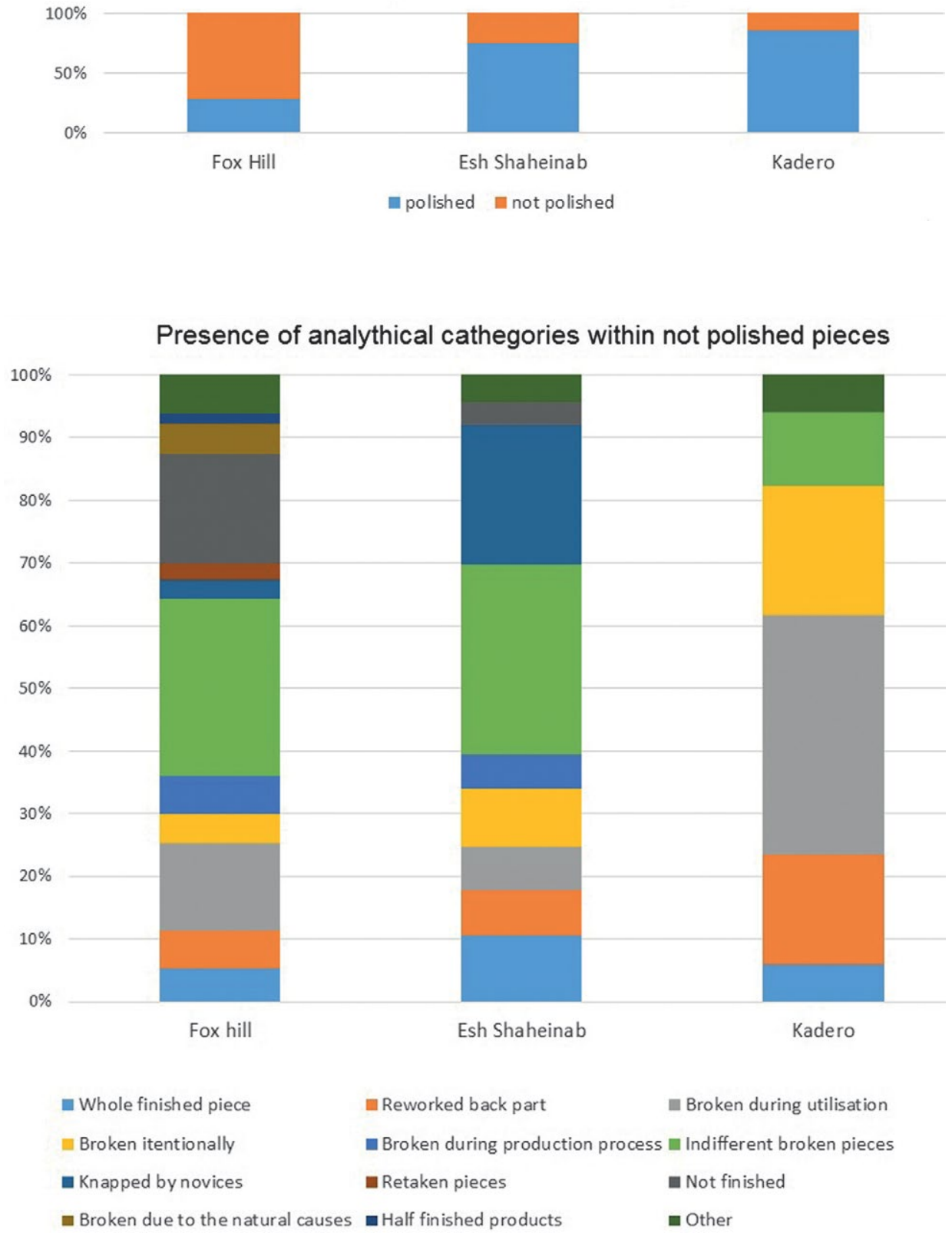

Fig. 5. Graph of ratio of different descriptive categories within presented sites (not polished pieces). Computer graphics: K. Kapustka. 

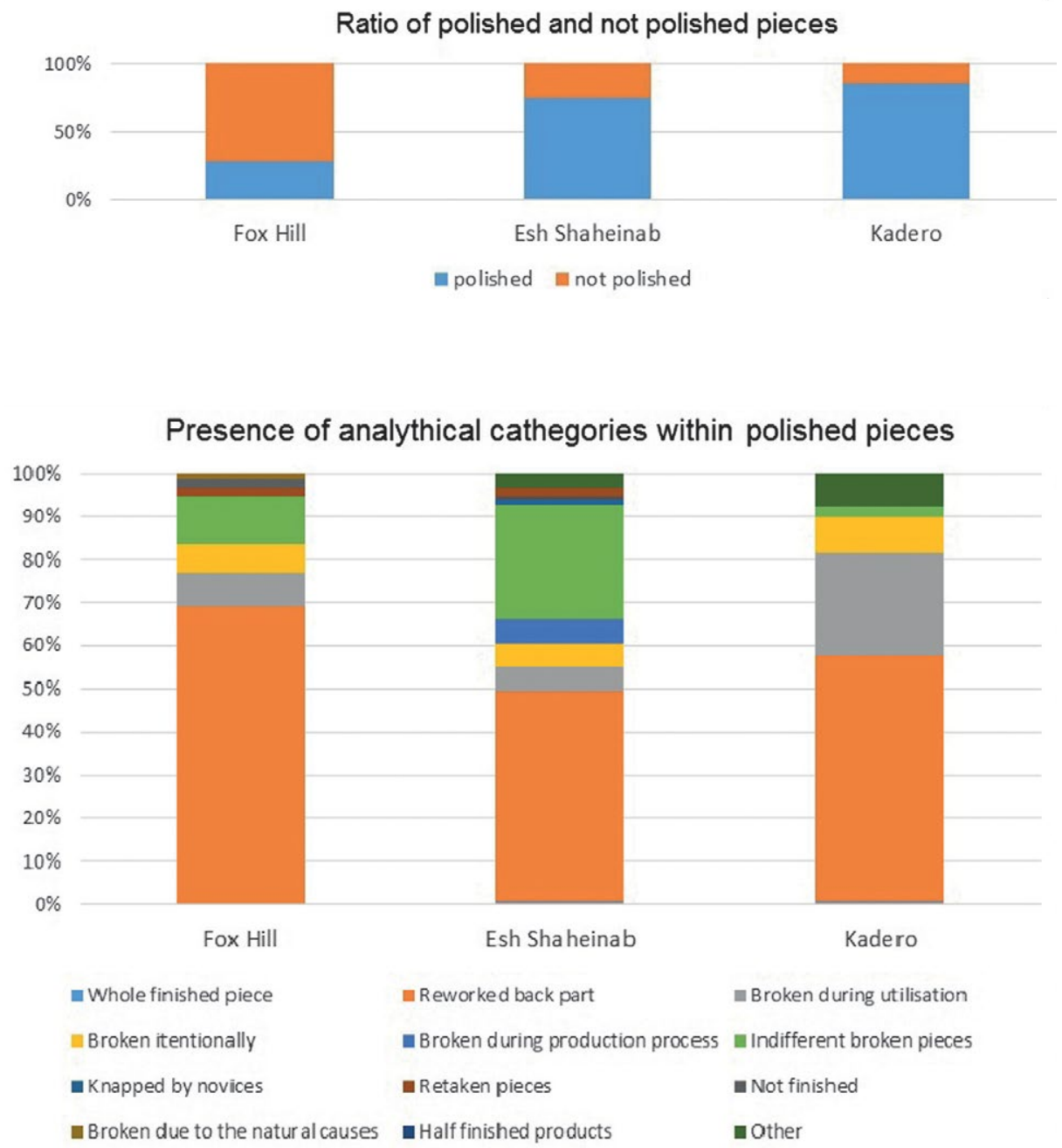

Fig. 6. Graph of ratio of different descriptive categories within presented sites (polished pieces). Computer graphics: K. Kapustka. 
${ }_{176}$ Katarina Kapustka and Matgorzata Winiarska-Kabaciniska

\begin{tabular}{|c|c|c|c|c|c|c|c|c|c|c|c|c|c|c|}
\hline \multirow{3}{*}{ قِّق } & త్ّ & $\hat{n}$ & $\underset{\forall}{*}$ & $\hat{2}$ & $\approx$ & in & $\overrightarrow{\mathrm{J}}$ & in & 2 & के & $\simeq$ & $\Downarrow$ & $\mathbb{n}^{+}$ & \\
\hline & 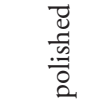 & 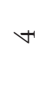 & $\underset{\forall}{\stackrel{\sim}{*}}$ & $\vec{\infty}$ & Fे & $\hat{\sim}$ & $\stackrel{\Re}{ \pm}$ & $\wedge$ & $\mathscr{m}$ & $m$ & $\neg$ & 0 & $\vec{n}$ & $\mathbb{R}$ \\
\hline & 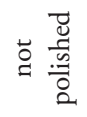 & $\vec{m}$ & $\tilde{\infty}$ & 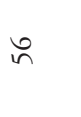 & $m$ & $\widetilde{\gamma}$ & $\stackrel{\infty}{=}$ & $\dddot{f}$ & $\bullet$ & 나 & $=$ & 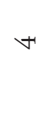 & $\ddot{\sim}$ & ঙ্ণ \\
\hline \multirow{3}{*}{ 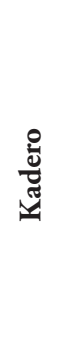 } & త్ّ & $n$ & $\vec{\Xi}$ & 8 & $\underset{\sim}{\sim}$ & 0 & $a$ & 0 & 0 & 0 & 0 & 0 & $\triangleq$ & है \\
\hline & 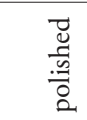 & - & $\cong$ & $\dot{\forall}$ & $\beth$ & 0 & in & 0 & 0 & 0 & 0 & 0 & $\cong$ & ః్ \\
\hline & 童 & $\sim$ & 0 & 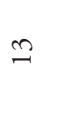 & $\wedge$ & 0 & 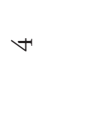 & 0 & 0 & 0 & 0 & 0 & $\sim$ & के \\
\hline \multirow{3}{*}{ 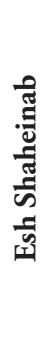 } & స్ّ & 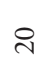 & $\underset{\sim}{\sim}$ & $\stackrel{\infty}{m}$ & $\vec{F}$ & $\stackrel{n}{2}$ & $\triangleq$ & $\stackrel{\leftrightarrow}{f}$ & $=$ & $\wedge$ & 0 & 0 & $\ddot{\sim}$ & สี้ \\
\hline & 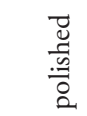 & $n$ & $\underset{\sim}{\sim}$ & $\hat{\sim}$ & $\stackrel{\sim}{\sim}$ & $\hat{\lambda}$ & $\stackrel{\infty}{\underset{\sim}{\beth}}$ & $\wedge$ & $=$ & - & 0 & 0 & $\stackrel{\bullet}{\sim}$ & $\stackrel{\infty}{\infty}$ \\
\hline & 竞 & $\beth$ & $\simeq$ & $\Xi$ & $\stackrel{\sim}{\sim}$ & $a$ & fे & $\stackrel{n}{2}$ & 0 & 6 & 0 & 0 & $\wedge$ & గ్ర \\
\hline \multirow{3}{*}{ 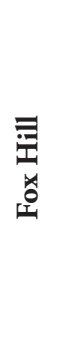 } & 『্ّ & 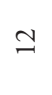 & $\hat{\wedge}$ & के & 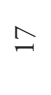 & $\Xi$ & $n$ & $\wedge$ & $\infty$ & $\not{\gamma}$ & $\simeq$ & t & $\underset{\sim}{\sim}$ & $\overrightarrow{\widetilde{n}}$ \\
\hline & 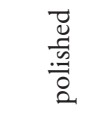 & 0 & 8 & $\wedge$ & 0 & 0 & 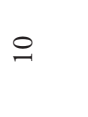 & 0 & $\sim$ & $\sim$ & - & 0 & 0 & $\bar{\sigma}$ \\
\hline & 兽 & $\simeq$ & $\stackrel{ \pm}{ \pm}$ & ஸు & $=$ & $\Xi$ & 6 & $\wedge$ & $\bullet$ & o & $=$ & 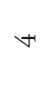 & 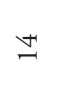 & ஷి \\
\hline$\stackrel{5}{-5}$ & $\begin{array}{l}\frac{5}{0.0} \\
\stackrel{0}{0}\end{array}$ & 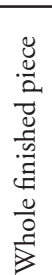 & 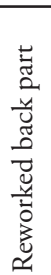 & 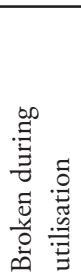 & 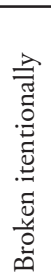 & 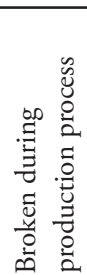 & 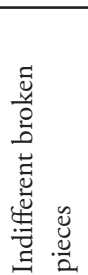 & 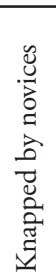 & 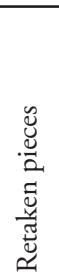 & 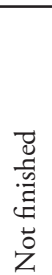 & 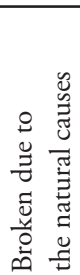 & 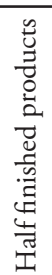 & 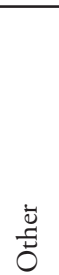 & قِ \\
\hline
\end{tabular}


\begin{tabular}{l|l} 
Comparison of Different Gouge Collections from Central Sudan & $\mathrm{I} 77$
\end{tabular}

\section{CONCLUSION}

This article is meant as a preliminary account of our research, which introduces elements of technological, use wear and experimental approaches to the study of gouges. However, even this preliminary study has revealed new information that widens our view on the problem of gouges.

It is our opinion that the path of research outlined here is most promising for confirming the use of gouges, which is often discussed but usually not studied by appropriate techniques. Preliminary results of use/wear analysis have helped us distinguish production traces from working traces and led us to the preliminary conclusion that gouges were used for woodworking, as has often been suggested before (Arkel 1953; Tixier 1962).

Our objective in future is to make series of experiments in tree cutting, wood working and working of other materials as well (e.g., bone, soil) to obtain use traces on the experimental pieces. By comparative study of these experimentally used pieces and their archaeological counterparts, we hope to specify the possible use of gouges in Sudanese prehistory in the case of the examples from the sites at Fox Hill and Kadero.

\section{ACKNOWLEDGEMENTS}

This work was accomplished with institutional support RVO: 67985912. The research for this paper was conducted as part of the Communities and resources in late prehistory of Jebel Sabaloka, Central Sudan: from analysis to synthesis project supported by the Czech Science Foundation (no. GAČR 17-03207S).

\section{REFERENCES}

Arkel, A. J. 1953. Shaheinab. An account of the excavation of a Neolithic occupation site carried out for the Sudan Antiquities Service in 1949-50. London

Caneva, I. 1988. El Geili. The history of a Middle Nile Environment 7000 BC-I500 AD. Oxford. Cambridge Monographs in African Archaeology 29. British Archaeological Reports International Series 424.

Caton-Thompson, G. and Gardner, E. W. 1934. The Desert Fayum. London.

Chłodnicki, M., Kobusiewicz, M. and Kroeper, K. (eds). 20II. Kadero: The Lech Krzyżaniak excavations in the Sudan. Poznan.

Haaland, R. 1981. Migratory herdsmen and cultivating women. The structure of Neolithic seasonal adaptation in the Khartoum Nile environment. Bergen.

Kapustka, K., Lisá, L., Bajer, A., Buriánek, D., Varadzin, L. and Varadzinová, L. 2019. Gouges: Towards the Understanding of an Iconic Artefact of the Early Neolithic Period in Central Sudan. African Archaeological Review 36: 505-534. 
I78 $\mid$ Katarina Kapustka and Matgorzata Winiarska-Kabacińska

Kobusiewicz, M. 20II. Lithic implements. In M. Chłodnicki, M. Kobusiewicz and K. Kroeper (eds), Kadero: The Lech Krzyzianiak excavations in the Sudan, 267-297. Poznan.

Krzyżaniak, L. 1992. Schytek pradziejów w środkowym Sudanie. Poznań. Studies in African Archaeology 3. Magid, A. A. 1989. Plant Domestication in the Middle Nile Basin. An Archaeoethnobotanical Case Study. Oxford. Cambridge Monographs in African Archaeology 35. British Archaeological Reports 523.

Tixier, J. 1962. Le “Ténéréen” de l’Adrar Bous III. In H. J. Hugot (ed.), Missions Berliet Ténéré-Tchad, 333-348. Paris, AMG.

Varadzinová, L., Varadzin, L., Kapustka, K. and Pacina, J. 20I8. Výzkum lokality Lišćí kopec (SBK.W-20) v pohoří Sabaloka: poznatky z výzkumné sezóny 2017. Pražské egyptologické studie 20: 35-45. 